\title{
Potencial Role of Stem Cell Therapy in Type 1 Diabetes Mellitus
}

\begin{abstract}
Type 1 diabetes mellitus is the result of the autoimmune response against pancreatic $\beta$-cell(s). At the time of clinical diagnosis near $70 \%$ of $\beta$-cell mass is been destroyed as a consequence of the auto-destruction that begins months or even years before the clinical diagnosis. Although marked reduction of chronic complications was seen after development and progression of insulin therapy over the years for type 1 diabetic population, associated risks of chronic end-organ damage and hypoglycemia still remain. Besides tight glucose control, $\beta$-cell mass preservation and/or increase are known to be other important targets in management of type 1 diabetes as long as it reduces chronic microvascular complications in the eyes, kidneys and nerves. Moreover, the larger the $\beta$-cell mass, the lower the incidence of hypoglycemic events. In this article, we discuss some insights about $\beta$-cell regeneration, the importance of regulation of the autoimmune process and what is being employed in human type 1 diabetes in regard to stem cell repertoire to promote regeneration and/or preservation of $\beta$-cell mass. (Arq Bras Endocrinol Metab 2008; 52/2:407-415)
\end{abstract}

Keywords: Diabetes mellitus; $\beta$-cell; Regeneration/preservation; Immune intervention; Stem cell; Transplant

\section{RESUMO}

\section{O Potencial das Células-Tronco no Tratamento do Diabetes Melito Tipo 1.}

O diabetes melito tipo 1 (DM1) é o resultado de uma resposta auto-imune contra as células-beta pancreáticas. Por ocasião do diagnóstico clínico do DM1, aproximadamente $70 \%$ da massa de células-beta foram destruídas como conseqüência de uma autodestruição que se iniciou há anos ou meses antes dos primeiros sinais da doença. Embora a redução acentuada das complicações crônicas na população com DM1 foi observada após o desenvolvimento e evolução da insulinoterapia, os riscos associados às lesões dos órgãos-alvo e hipoglicemia persistem. Além do controle intensivo da glicemia, a preservação e/ou o aumento da massa de células-beta são reconhecidos como alvos importantes no tratamento do DM1. Isto vem associado à redução das complicações crônicas microvasculares na retina, rins e nervos e a menor incidência de eventos hipoglicêmicos. Neste artigo, discutimos alguns aspectos da regeneração das células-beta pancreáticas, a importância da regulação do processo auto-imune e o que está sendo empregado no DM1 humano com relação ao repertório das células-tronco nesse sentido. (Arq Bras Endocrinol Metab 2008;52/2:407-415)

Descritores: Diabetes tipo 1; Células-beta; Regeneração/preservação; Imunoterapia; Células-tronco; Transplante revisão

\author{
Carlos Eduardo Barra Courl \\ JúlIo CÉsar VoltarelLI
}

Department of Clinical Medicine. School of Medicine of Ribeirão Preto. University of São Paulo, Ribeirão Preto, SP, Brazil. 


\section{INTRODUCTION}

$\mathrm{T}$ YPE 1 DiABETES MELLITUS (TIDM) results from a cell-mediated autoimmune attack against pancreatic $\beta$-cells. The autoimmune response may begin years before the clinical diagnosis. Since more than 70-80\% of $\beta$-cell mass has been destroyed at the time of disease onset, the autoimmune process is markedly advanced when hyperglycemia appears $(1,2)$ (Figure 1 ).

The pancreatic microenvironment is considered to be the primary location of autoreactive T-cells in TIDM. However, in animal models the presence of autoreactive diabetogenic T-cells have also been detected in the spleen (3) and bone marrow (4) of NOD mice and this presence can also be detected long before clinical onset of the disease.

The rate of $\beta$-cell destruction in the preclinical phase is rapid in children associated with much less $\beta$-cell mass at the time of diagnosis; in contrast, in adults the rate of auto-destruction is slower, with larger $\beta$-cell mass at diagnosis (5). Another predictor of the poor amount of viable $\beta$-cell mass at diagnosis is the presence of high-risk major histocompatibility complex, such as $\mathrm{DRBl}{ }^{*} 03$ $\mathrm{DQB1}{ }^{*} 0201 / \mathrm{DRB1}{ }^{*} 04-\mathrm{DQB} 1{ }^{*} 0302$ (6). Moreover, some investigators argue in favor of sex differences in $\beta$-cell mass at clinical presentation of TIDM, being $\beta$-cell destruction more extensive in post-pubertal females than males. Such difference was not observed in pubertal or pre-pubertal individuals (7).
Studies of pathologic anatomy of pancreas from patients soon after the diagnosis of TIDM suggest that approximately $10-20 \%$ of normal $\beta$-cell mass still remains. Interestingly, functional analysis of newly diagnosed patients indicates that average total insulin secretion in response to a mixed meal is around $50 \%$ of that seen in matched non-diabetic population (8).

\section{GLUCOSE CONTROL IS NOT THE UNIQUE FOCUS IN THE MANAGEMENT OF T1DM}

Blood glucose control is the most important target in the management of diabetes mellitus. Since patients with TIDM depend on daily exogenous insulin administration for survival, the best-established goal is tight control of glucose levels achieved by multiple daily injections or continuous subcutaneous infusion of insulin, ie, intensive insulin therapy. This treatment is known to reduce the risk of microvascular complications by $35 \%$ to $90 \%$ when compared with conventional therapy with only 1 to 2 injections per day (9), but is not the only way to prevent chronic complications in individuals with TIDM. Moreover, even in the most strictly-controlled patients, associated risks of chronic end-organ damage and hypoglycemia still remain.

Subgroup analysis of the Diabetes Control and Complication Trial (DCCT) has showed an important aspect related to long term complications of the disease, ie, patients with higher serum levels of C-peptide

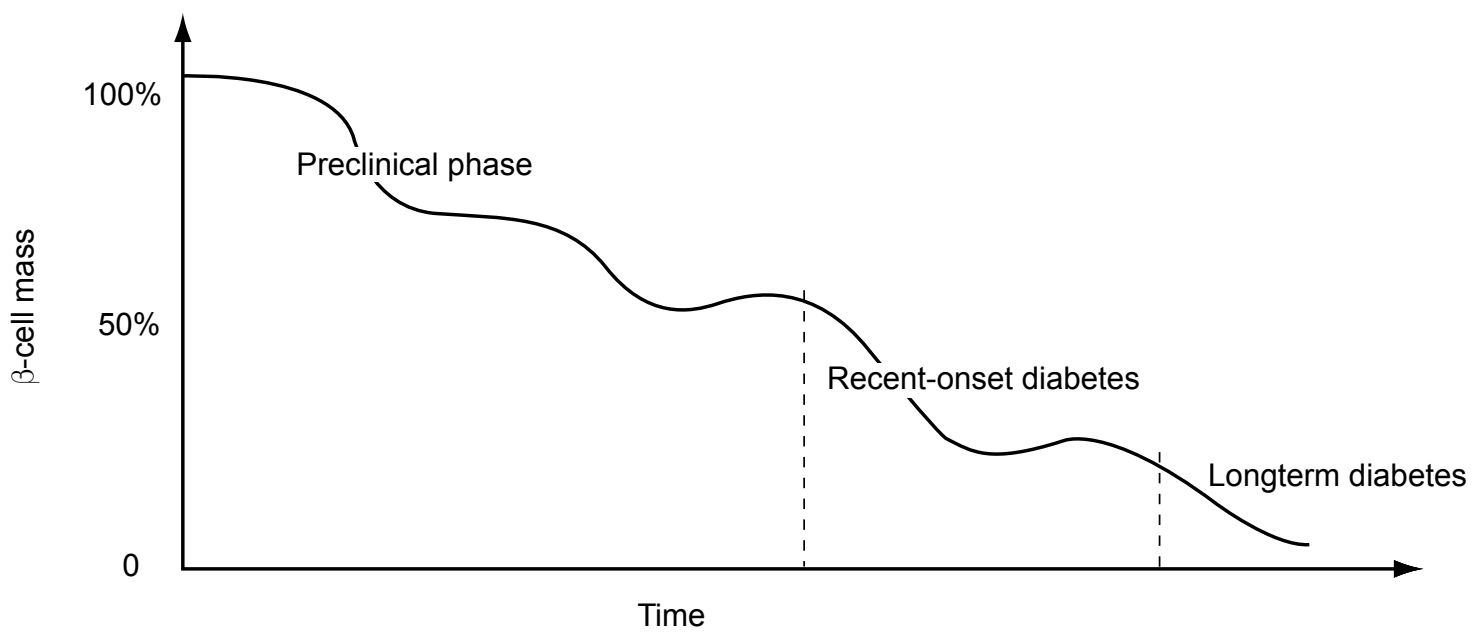

Figure 1 Schematic rate of $\beta$-cell destruction function of different phases of type 1 diabetes mellitus preclinical phase, recent diagnosis and longterm disease. 
after diagnosis with sustained levels over the years suffered less microvascular complications and less hypoglycemic events than those patients with low or undetected levels of C-peptide. In conclusion, $\beta$-cell preservation is another important target in the management of TIDM and its related complications (10).

In non-diabetic population $\beta$-cell mass changes in response to different physiological and pathologic process during adult life such as pregnancy, abdominal obesity and states of insulin resistance $(11,12)$. This phenomenon of $\beta$-cell adaptation in face of innumerous challenges experienced after birth is resultant of neogenesis, proliferation or apoptosis (13).

Plasticity and spontaneous regeneration capacity of $\beta$-cell mass can be demonstrated in animal models or in humans. In normal animals or in rat diabetic models, chronic high-dose glucose infusion protocols showed increase in cell mass, in cell function, in neogenesis and in cell replication indices (14-17). In another study, young near-totally-pancreatectomized rats presented a spontaneous eight-week-regeneration of $27 \%$ of pancreas weight and $42 \%$ of the endocrine pancreas (18). In contrast, a recent study in humans has failed to evidence $\beta$-cell proliferation after partial pancreatectomy (19). However, an impressive Japanese case report showed more insights about $\beta$-cell regeneration in humans: a 39-year-old type 1 diabetic patient submitted to simultaneous pancreas-kidney transplantation was referred to treat an abdominal incision herniation 2 years after the initial procedure. A regimen with tacrolimus, prednisolone and micophenolate was used since transplantation and good glycemic control was achieved without exogenous insulin. At the time of the corrective surgery, native pancreas biopsy showed that the percent of $\beta$-cells was 4 fold greater than that observed in long term type 1 diabetic patients conventionally treated with insulin (20).

\section{INSIGHTS ABOUT $\beta$-CELL REGENERATION}

In light of recent discoveries demonstrating the regenerative potential of the pancreas, many researches have been made with the aim of identifying which cell or cells could be the precursors of adult cells. The clonal isolation of putative pancreatic precursors has been an elusive objective of researchers who look for a more complete knowledge of $\beta$-cell physiology and for new replacement strategies for TIDM.
The presence of a group of characteristics is necessary to indicate if a progenitor cell is able to differentiate into pancreatic cells. It includes: insulin staining, presence of activated specific cell genes, progressive insulin secretory pattern in vitro in response to greater glucose concentration of the medium, and reversal or prevention of hyperglycemia in animal models of TIDM after progenitor cell administration.

The great majority of studies of cell precursors were developed in animal models and each protocol has its own pros and cons $(21,22)$. Several candidate precursors of adult cells were studied:

- adult pancreatic cell itself (23-25);

- pancreas-derived multipotent progenitor (26);

- pancreatic duct cells (27);

- bone marrow-derived mesenchymal stem cells (28-31);

- bone marrow-derived hematopoietic stem cells (32-35);

- hepatic oval cells (36-38);

- $\quad$ spleenocytes $(39,40)$;

- umbilical cord blood cells $(21,42,43)$;

- embryonic stem cells $(44,45)$.

As mentioned above, a variety of tissues harbors progenitor or stem cells. The pancreas is an obvious source tissue and a number of studies have suggested the existence of stem cells within the pancreas. What is not exactly known is if pancreas-derived progenitor cells are primarily inside pancreatic parenchyma since early pancreas embryogenesis, or if these cells have other sources (bone marrow or duct cells, for example) and then migrated to the pancreatic tissue. Another hypothesis is that pancreatic duct cells differentiate into pancreatic $\beta$-cells and it was widely studied in animal models (27). Recently, Yatoh and colleagues have showed that pancreatic duct cells purified from islet-depleted human tissue can differentiate in vitro to insulin producing cells (46).

Bone marrow is another important probable source of adult $\beta$-cells and among cell population presented in bone marrow mesenchymal stem cells have more notorious impact in this regard. In 2004, Chen and colleagues (29) induced in vitro $\beta$-cell differentiation under appropriate conditions. These cells evidenced glucose-dependent insulin secretion in vitro and, when transplanted into streptozotocin-induced diabetic rats, 
could down-regulate blood glucose levels. In 2006, Lee and colleagues (30) showed a decrease in glucose levels, an increase in $\beta$-cell mass and pancreatic islets in $\mathrm{NOD} /$ scid mice that received intracardiac human mesenchymal stem cells. Additionally, these infused cells also promoted adjuvant effects in the kidneys by decreasing mesangial thickening and by reducing macrophage infiltration. Recently, Urbán and colleagues (31) have showed that mesenchymal stem cells, aside of promoving $\beta$-cell regeneration in streptozotocin-induced diabetic mice, inhibit T-cell-mediated immune response against newly-formed $\beta$-cells in which are able to survive in this altered imunological milieu.

A less promising scenario is seen in studies of hematopoietic stem cells. As bone marrow hematopoietic stem cells were able to differentiate into hepatocytes and ultimately regenerate liver in animal models $(32,33)$, attempts were made to evaluate their possible role in $\beta$-cell regeneration. However, Kang and colleagues (34) showed that hematopoietic stem cell transplantation prevents diabetes in NOD mice but does not contribute to significant islet cell regeneration once the disease is established. Moreover, in 2007 Butler and colleagues (35) evaluated 31 human pancreata obtained at autopsy from hematopoietic stem cell transplant recipients who had received their transplant from a donor of the opposite sex. In this study, in spite of observing donor-derived cells in the non-endocrine pancreata, they did not demonstrate the presence of donor-derived $\beta$-cells.

Umbilical cord blood (UCB) is an important source of stem cells and regulatory $\mathrm{T}$ cells, with potential to promote in vivo $\beta$-cell regeneration. Moreover, much attention is kept on their immunomodulatory effects in autoimmune diseases. In a xenogenic model of stem cell transplantation, human mononuclear UCB cells were able to reduce blood glucose levels and increase survival in mouse models of type 1 and type 2 diabetes mellitus (41). In other animal model of diabetes (type $2)$, UCB cell infusion also improved renal abnormalities and neuropathy caused by diabetes, suggesting a regenerative action in renal parenchyma and nerves $(42,43)$. These dual effects - regenerative and immunomodulatory - are of great importance in the regard of autoimmune TIDM and as previously seen, this capacity is also seen in studies of mesenchymal stem cells $(31,47,48)$.

Embryonic stem cells (ESC) are pluripotent cell lines derived from the inner cell mass of blastocyst- stage embryos and their differentiation in culture may reproduce characteristics of early embryonic development. For this reason, ESC are considered as having unlimited potential in generating differentiated adult cells, including pancreatic $\beta$-cells. Beginning in 2000 , it has been reported by many research groups that ESC can differentiate into $\beta$-cells in vitro. In 2001, Assady and colleagues (49), using human ESC, evidenced the spontaneous in vitro differentiation of cells with specific characteristics of $\beta$-cell in both adherent and suspension culture conditions. After embryoid body development, $3 \%$ of all cells positively stained for insulin at a maximal density evidenced markers of $\beta$-cell identity, such as glucose transporter protein GLUT2 and glucokinase genes, Pdx-1/Ipf- 1 and neurogenin-3 transcription factors. Functional analyses evidenced secretion of insulin into the medium in response to different glucose concentrations.

Stimulated by several recent reports claiming the generation of insulin-producing cells from ESC, Hansson et al. (50) investigated the properties of these insulin-containing progenitors. In this study they found that although differentiated cells containing immunoreactive insulin has been isolated, they did not contain proinsulin-derived C-peptide. Furthermore, in spite of variable insulin release from these cells upon glucose addition, C-peptide release was never detected. Thus, the authors suggest that $\mathrm{C}$-peptide biosynthesis and secretion should be demonstrated to claim insulin production from embryonic stem cell progeny.

Another point related to ESC is the ethical issues surrounding stem cell therapy. Discussions are complex and involve not only technical aspects but also philosophical questions related to the beginning of individual life (51). Other ways have been developed to solve those ethical problems. Recently, Byrne and colleagues (52) have used a modified somatic cell nuclear transfer approach to produce rhesus macaque blastocysts from adult skin fibroblasts, and successfully isolated two ESC lines from these embryos. DNA analysis confirmed that nuclear DNA was identical to donor somatic cells and that mitochondrial DNA originated from oocytes.

In autoimmune diseases the potential role of stem cell therapy is somewhat different from pure degenerative diseases. For example, in cases of myocardial infarction, it seems obvious to use stem cells to regenerate necrotic tissue. However, in TIDM the regenerative process of $\beta$-cell mass using stem cell therapy should be associated with safe strategies of immunomodulation to 
block autoimmunity against newly differentiated $\beta$-cells formed by stem cell transplantation $(22,53)$. In Figure 2 , we summarize potential use of stem cell therapy associated with immunomodulatory approaches in individuals with TIDM in different clinical settings. It is important to note that in recent-onset or even in preclinical phase, immunomodulatory strategies can be done as the unique therapeutic approach since larger residual $\beta$-cell mass is still functioning and able to be preserved. Moreover, immunomodulation secondarily facilitates endogenous mechanisms of $\beta$-cell proliferation once the pathologic process of $\beta$-cell destruction is blocked.

\section{STUDIES INVOLVING STEM CELL THERAPY IN HUMAN T1DM}

\section{Autologous nonmyeloablative hematopoietic stem cell transplantation}

In 2003, our research group started an original study of autologous nonmyeloablative hematopoietic stem cell transplantation in patients with newly diagnosed
TIDM. The objective of the treatment is to stop autoimmune destruction of $\beta$-cells with high-dose immunosuppressive drugs (cyclophosphamide and rabbit antithymocyte globulin) and to "reset" the deleterious immunologic system with a reconstituted one originated from autologous hematopoietic stem cells (54). The rational is to preserve residual $\beta$-cell mass and facilitate endogenous mechanisms of $\beta$-cell regeneration. As shown above, hematopoietic stem cells do not have the capacity to differentiate into $\beta$-cells. So, in this case, hematopoietic stem cells are used solely to regenerate a "renewed" autoimmune system without previous immunologic memory against pancreatic antigens.

The exact mechanism operating in this protocol is unclear, but it may shift the balance between destructive immunity and tolerance through yet undefined mechanisms such as clonal exhaustion, suppressor cells, immune indifference, cytokine alterations, changes in $\mathrm{T}$ - or $\beta$-cell clonality or changes in immunodominant autoantigens (55).

The first patient enrolled presented discouraging response. His insulin requirements increased progressively until 12 months following transplantation (when
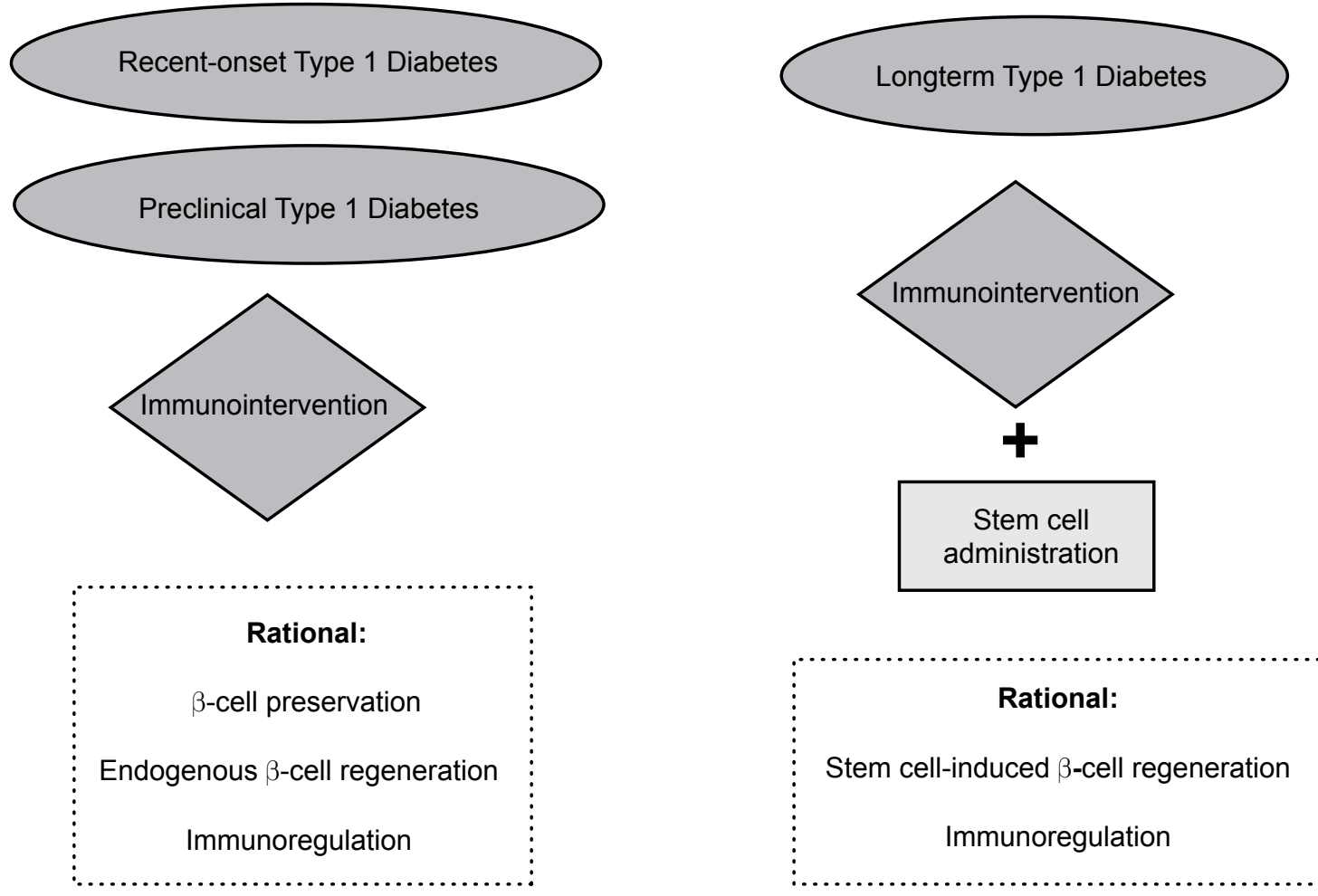

Figure 2 Potential therapeutic use of stem cell therapy for patients with type 1 diabetes mellitus in three distinct clinical settings: newly-diagnosed type 1 diabetes, pre-clinical and long-term type 1 diabetes. 
he abandoned follow-up) reaching the dose $250 \%$ higher than his initial requirement. His hemoglobin Alc was $11.1 \%$ at 12 months and his C-peptide concentrations did not increase. The possible causes for his poor clinical response are the very low $\beta$-cell reserve predicted by the previous diagnosis of diabetic ketoacidosis that was further jeopardized by $\beta$-cell apoptotic effect of glucocorticoids used in the conditioning regimen to prevent possible rabbit antithymocyte globulin reactions. In face of this, we decided not to use glucocorticoids in the conditioning regimen in the following patients and did not include those with previous diabetic ketoacidosis.

During a mean follow-up of 23.8 months (range between 1 to 45 months) in November 2007, all the subsequent 18 patients became insulin-free, most of them shortly after starting high dose immunosuppression and even before stem cell infusion. Of these 18 patients, 4 resumed insulin use after transient periods free from insulin ranging from 7 to 12 months. The other 14 patients are continuously without insulin use since insulin suspension: 3 patients for at least 3 years,
4 patients for at least 2 years, 3 patients for at least 1 year and 3 patients for at least 3 months (Figure 3 ). The $19^{\text {th }}$ patient was just a few days free from insulin.

There was a statistically significant reduction of mean hemoglobin Alc concentrations after transplantation. All but 2 patients (the $1^{\text {st }}$ and the $11^{\text {th }}$ ) presented all measurements below 7\% (upper limit of good glucose control) during follow-up. As noted above, soon after inclusion, the $1^{\text {st }}$ patient did not achieve good glucose control. The $11^{\text {th }}$ patient presented Alc levels $<7 \%$ until 12 months after transplantation when insulin use was restarted and hemoglobin Alc began to increase.

With respect to time course of $\beta$-cell function of the first 14 patients who had C-peptide levels analyzed, the majority $(\mathrm{n}=1 \mathrm{l})$ presented increased values in comparison with pretreatment levels, indicating preservation and even improvement $\beta$-cell function. Analyzing C-peptide levels during a stimulus with mixed meal tolerance test, there was a statistically significant increase in mean area under the curve 6 months after transplantation and this increase was maintained until 24 months after stem cell transplantation.

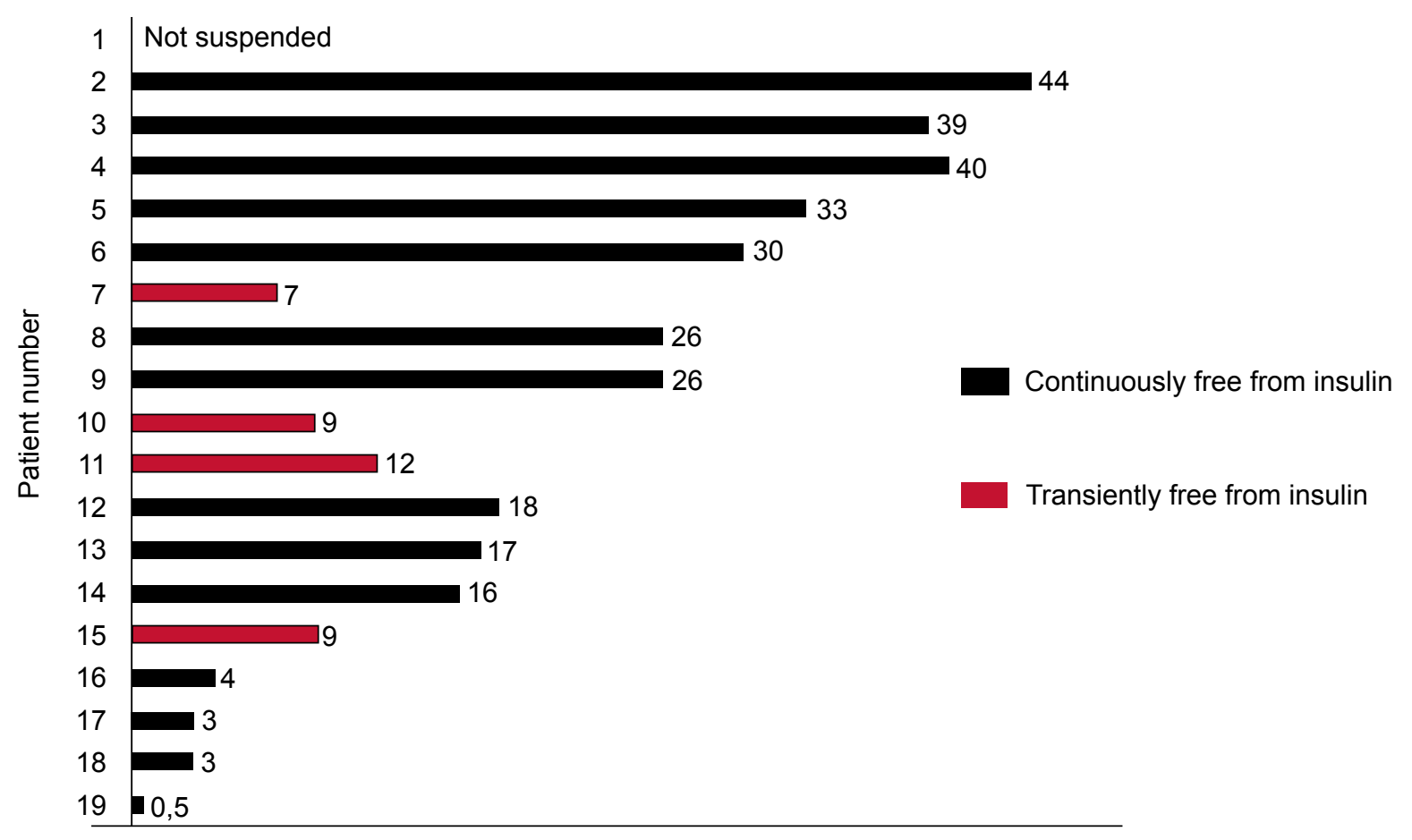

Time free from insulin (months)

Figure 3 Time free from insulin of the first 10 patients with type 1 diabetes enrolled for autologous nomyeloablative hematopoietic stem cell transplantation. 
In face of the good metabolic results presented, the adverse effects were acceptable. With respect to acute complications, most patients had febrile neutropenia, nausea, vomiting, alopecia due to the drugs used in the study protocol, especially immunosuppressive agents. Bilateral pneumonia of unidentified etiology that required supplementary oxygen therapy and responded completely to broad-spectrum antibiotics occurred in patient 2 and was the only severe acute complication of ASCT. During long-term follow-up, patient 2 presented Graves disease identified 3.5 years after transplantation, patient 3 developed autoimmune hypothyroidism and transient renal dysfunction associated with rhabdomyolysis, a complication that was successfully treated with levothyroxine presented mild transient hypergonadotropic hypogonadism 12 months after transplantation. These late onset endocrine dysfunctions presented by these 3 patients can be related to the transplant procedure itself or by autoimmune polyendocrine syndrome frequently associated with TIDM. There was no mortality.

In July 2007 we developed a similar study of nomyeloablative autologous hematopoietic stem cell transplantation solely in newly diagnosed individuals with TIDM who presented previous diabetic ketoacidosis. By November 2007 only one patient had been enrolled in the study, insulin independence was not achieved, but insulin doses decreased by less than $50 \%$ of the initial requirements.

\section{Autologous umbilical cord blood transfusion}

In 2007, Haller and colleagues presented preliminary data on the metabolic effects of autologous umbilical cord blood transfusion in 7 diabetic children with recent-onset TIDM (56). As seen above, the rational of the use of this source of stem cells is to promote both immunoregulation and $\beta$-cell regeneration.

Mean age of the enrolled patients was 4.4 years, mean time since diagnosis was 9.6 months and mean daily insulin requirements was $0.45 \mathrm{IU} / \mathrm{kg} /$ day. During a follow-up of only 6 months, patients who received umbilical cord blood transfusion presented lower hemoglobin Alc levels associated with lower insulin requirements when compared to children who received insulin therapy alone. However, spite of the short follow-up, C-peptide levels have declined and no patient became insulin-free.

\section{Bone marrow mononuclear cells}

Cell therapy groups in Argentina and Peru have been using unfractionated bone marrow mononuclear cells via splenic artery to treat long standing type $l$ and type 2 diabetic patients. The proposed mechanism is the angiogenic activity of bone marrow cells in the pancreas improving $\beta$-cell function. In patients with TIDM, intra-arterial infusion of bone marrow cells in the pancreas showed no metabolic improvement after 1 year of follow-up as expressed by no reductions in hemoglobin Alc and in daily insulin requirements and by no increase in C-peptide levels (57). Moreover, these results are expected to be replicated in larger controlled trials and be fully published in peer-reviewed journals.

\section{ACKNOWLEDGEMENT}

This article was supported by FAEPA-HCRD, FUN+ DHERP, CNPq and FINEP

\section{REFERENCES}

1. Notkins $A L$, Lernmark A. Autoimmune type 1 diabetes: resolved and unresolved issues. J Clin Invest. 2001; 108:1247-52.

2. Gepts W. Pathologic anatomy of the pancreas in juvenile diabetes mellitus. Diabetes. 1965;14:619-33.

3. Matsumoto M, Yagi H, Kunimoto K, Kawaguchi J, Makino S, Harada M. Transfer of autoimmune diabetes from diabetic NOD mice to NOD athymic nude mice: the roles of T-cell subsets in the pathogenesis. Cell Immunol. 1993;148:189-97.

4. Li R, Perez N, Karumuthil-Melethil S, Vasu C. Bone Marrow Is a Preferential Homing Site for Autoreactive T-Cells in Type 1 Diabetes. Diabetes. 2007;56:2251-9.

5. Pozzilli P, Di Mario U. Autoimune diabetes not requiring insulin at diagnosis (latent autoimune diabetes of the adult). Diabetes Care. 2001;24:1460-7.

6. Petrone A, Galgani A, Spoletini M, Alemanno I, Di Cola S, Bassotti $G$, et al. Residual insulin secretion at diagnosis of type 1 diabetes is independently associated with both, age of onset and HLA genotype. Diabetes Metab Res Rev. 2005;21: 271-5.

7. Pozzilli P, Mesturino CA, Crino A, Gross TM, Jeng LM, Visalli N IMDIAB Group. Is the process of beta-cell destruction in type 1 diabetes at time of diagnosis more extensive in females than in males? Eur J Endocrinol. 2001; 145:757-61.

8. Steele C, Hagopian WA, Gitelman S, Masharani U, Cavaghan $\mathrm{M}$, Rother $\mathrm{KI}$, et al. Insulin secretion in type 1 diabetes. Diabetes. 2004;53:426-33.

9. The Epidemiology of Diabetes Interventions and Complications Research Group. The effect of intensive insulin therapy on the microvascular complications of type 1 diabetes mellitus. JAMA. 2002;287:2563-69. 
10. The Diabetes Control and Complications Trial Research Group Effect of intensive therapy on residual beta-cell function in patients with type 1 diabetes in the Diabetes Control and Complications Trial. Ann Intern Med. 1998;128:517-23.

11. Swenne I. Pancreatic $\beta$-cell growth and diabetes mellitus. Diabetologia. 1992;35:193-201.

12. Fernandes A, King LC, Guz Y, Stein R, Wright CV, Teitelman G. Differentiation of new insulin-producing cells is induced by injury in adult pancreatic islets. Endocrinology. 1997;138:1750-62.

13. Bonner-Weir S, Sharma A. Pancreatic stem cell. J Pathol. 2002;197:519-26.

14. Sako Y, Grill VE. Coupling of beta-cell desensitization by hyperglycemia to excessive stimulation and circulating insulin in glucose-infused rats. Diabetes. 1990;39:1580-3.

15. Bernard C, Berthault MF, Saulnier C, Ktorza A. Neogenesis vs. apoptosis as main components of pancreatic beta-cell as changes in glucose-infused normal and mildly diabetic adult rats. FASEB J. 1999;13:1195-205.

16. Bonner-Weir S, Deery D, Leahy JL, Weir GC. Compensatory growth of pancreatic $\beta$-cells in adult rats after short-term glucose infusion. Diabetes. 1989;38:49-53.

17. Topp BG, McArthur MD, Finegood DT. Metabolic adaptations to chronic glucose infusion in rats. Diabetologia. 2004;47:1602-10.

18. Bonner-Weir S, Trent DF, Weir GC. Partial pancreatectomy in the rat and subsequent defect in glucose-induced insulin release. J Clin Invest. 1983;71:1544-53.

19. Menge BA, Tannapfel A, Belyaev O, Drescher R, Müller C, Uhl $W$, et al. Partial pancreatectomy in adult humans does not provoke beta-cell regeneration. Diabetes. 2007; [Epub ahead of print].

20. Kuroda A, Yamasaki Y, Imagawa A. $\beta$-Cell Regeneration in a Patient with Type 1 Diabetes Mellitus Who Was Receiving Immunosuppressive Therapy. Ann Intern Med. 2003;139:81.

21. Burns CJ, Persaud SJ, Jones PM. Stem cell therapy for diabetes: do we need to make beta-cells? J Endocrinol 2004;183:437-43.

22. Couri CE, Foss MC, Voltarelli JC. Secondary prevention of type 1 diabetes mellitus: stopping immune destruction and promoting beta-cell regeneration. Braz J Med Biol Res. 2006;39:1271-80.

23. Georgia $S$, Blushan A. $\beta$-cell replication is the primary mechanism of maintaining postnatal $\beta$-cell mass. J Clin Invest. 2004;114:963-8.

24. Dor Y, Brown J, Martinez OI, Melton DA. Adult pancreatic betacells are formed by self-duplication rather than stem-cell differentiation. Nature. 2004;429:41-6.

25. Nir T, Melton DA, Dor Y. Recovery from diabetes in mice by beta cell regeneration. J Clin Invest. 2007;117:2559-61.

26. Seaberg R, Smukler SR, Kieffer TJ, et al. Clonal identification of multipotent precursors from adult mouse pancreas that generate neural and pancreatic lineages. Nat Biotechnol. 2004;22:1115-24.

27. Bonner-Weir S, Taneja M, Weir GC, et al. In vitro cultivation of human islets from expanded ductal tissue. Proc Natl Acad Sci USA. 2000;97:7999-8004.

28. Jiang $\mathrm{Y}$, Jahagirdar BN, Reinhardt RL, et al. Pluripotency of mesenchymal stem cells derived from adult bone marrow. Nature. 2002;418:41-9.

29. Chen LB, Jiang XB, Yang L. Differentiation of rat marrow mesenchymal stem cells into pancreatic islet beta-cells. World $\mathrm{J}$ Gastroenterol. 2004;10:3016-20.
30. Lee RH, Seo MJ, Reger RL, et al. Multipotent stromal cells from human marrow home to promote repair of pancreatic islets and renal glomeruli in diabetic NOD/scid mice. Proc Natl Acad Sci USA. 2006;103:17438-43.

31. Urbán VS, Kiss J, Kovács J, et al. Mesenchymal Stem Cells Cooperate with Bone Marrow Cells in Therapy of Diabetes. Stem Cells 2007; Oct 11 [Epub ahead of print].

32. Lagasse $\mathrm{E}$, Connors $\mathrm{H}, \mathrm{Al}$-Dhalimy M et al. Purified hematopoietic stem cell can differentiate into hepatocytes in vivo. Nat Med. 2000;6:1229-34.

33. Theise ND, Badve S, Saxena R, et al. Derivation of hepatocytes from bone marrow cells in mice after radiation-induced myeloablation. Hepatology. 2000;31:235-40.

34. Kang EM, Zickler MM, Burns S et al. Hematopoietic stem cell transplantation prevents diabetes in NOD mice but does not contribute to significant islet cell regeneration once disease is established. Exp Hematol. 2005;33:699-705.

35. Butler AE, Huang A, Rao PN, et al. Hematopoietic stem cells derived from adult donors are not a source of pancreatic-cells in adult nondiabetic humans. Diabetes. 2007;56:1810-16.

36. Petersen BE, Goff JP, Greenberger JS, Michalopoulos GK. Hepatic oval cells express the hematopoietic stem cell marker Thy-1 in the rat. Hepatology. 1998;27:433-5.

37. Yang L, Li S, Hatch $H$, et al. In vitro transdifferentiation of adult hepatic stem cells into pancreatic endocrine hormone-producing cells. Proc Natl Acad Sci USA. 2002;99:8078-83.

38. Kim S, Shin JS, Kim HJ, Fisher RC, Lee MJ, Kim CW. Streptozotocin-induced diabetes can be reversed by hepatic oval cell activation through hepatic transdifferentiation and pancreatic islet regeneration. Lab Invest. 2007;87:702-12.

39. Kodama S, Kühtreiber W, Fujimura S, Dale EA, Faustman DL. Islet regeneration during the reversal of autoimmune diabetes in NOD mice. Science. 2003;14:1223-7.

40. Chong AS, Shen J, Tao J, Yin D, Kuznetsov A, Hara M, et al. Reversal of diabetes in non-obese diabetic mice without spleen cell-derived beta-cell regeneration. Science. 2006;311:1774-5

41. Ende N, Chen R, Reddi AS. Effect of human umbilical cord blood cells on glycemia and insulitis in type 1 diabetic mice. Biochem Biophys Res Commun. 2004;325:665-9.

42. Ende N, Chen R, Reddi AS. Transplantation of human umbilical cord blood cells improves glycemia and glomerular hypertrophy in type 2 diabetic mice. Biochem Biophys Res Commun. 2004;321:168-71.

43. Naruse K, Hamada Y, Nakashima E, et al. Therapeutic neovascularization using cord blood-derived endothelial progenitor cells for diabetic neuropathy. Diabetes. 2005;54:1823-8.

44. Yang L, Li S, Hatch $\mathrm{H}$, et al. In vitro transdifferentiation of adult hepatic stem cells into pancreatic endocrine hormone-producing cells. Proc Natl Acad Sci USA 2002;99:8078-83.

45. Kim S, Shin JS, Kim HJ, Fisher RC, Lee MJ, Kim CW. Streptozotocin-induced diabetes can be reversed by hepatic oval cell activation through hepatic transdifferentiation and pancreatic islet regeneration. Lab Invest. 2007;87:702-12.

46. Yatoh S, Dodge R, Akashi T, Omer A, Sharma A, Weir GC, et al. Differentiation of affinity-purified human pancreatic duct cells to beta-cells. Diabetes. 2007;56:1802-9.

47. Le Blanc K, Ringdén O. Mesenchymal stem cells: properties and role in clinical bone marrow transplantation. Curr Opin Immunol. 2006;18:586-91. 
48. Ryden M, Dicker A, Gotherstrom C, Astrom G, Tammik C, Arner $P$, et al. Functional characterization of human mesenchymal stem cell-derived adipocytes. Biochem Biophys Res Commun. 2003;311:391-7.

49. Assady S, Maor G, Amit M, Itskovitzs-Eldor J, Skorecki KL, Tzukerman M. Insulin production by human embryonic stem cells. Diabetes. 2001;50:1691-7.

50. Hansson M, Tonning A, Frandsen $U$, et al. Artifactual insulin release from differentiated embryonic stem cells. Diabetes. 2004;53:2603-9.

51. Hughes IA. A perspective on stem cells by a clinician. Eur J Endocrinol. 2004;151:U3-5.

52. Byrne JA, Pedersen DA, Clepper LL, Nelson M, Sanger WG, Gokhale S, et al. Producing primate embryonic stem cells by somatic cell nuclear transfer. Nature. 2007;450:497-502.

53. Trucco M. Regeneration of the pancreatic $\beta$-cell. J Clin Invest. 2005;115:5-12.

54. Voltarelli JC, Couri CEB, Stracieri ABPL, et al. Autologous nonmyeloablative hematopoietic stem cell transplantation in newly diagnosed type 1 diabetes mellitus. JAMA, 2007;297: 1568-76.
55. Burt RK, Slavin S, Burns WH, Marmont AM. Induction of tolerance in autoimmune diseases by hematopoietic stem cell transplantation: Getting closer to a cure? Blood. 2002;99:768-84.

56. Haller MJ, Viener H, Brusko T, Wasserfall C, Mcgril K, Staba S, et al. Insulin requeirements, $\mathrm{HbA} 1 \mathrm{c}$, and stimulated $\mathrm{C}$-peptide following autologous umbilical cord blood transfusion in children with T1D. American Diabetes Association $67^{\text {th }}$ Scientific Sessions; 2007 June 22-26; Chicago. Alexandria: American Diabetes Association Publisher; 2007. A82 p.

57. Tuma-Mubarak J, Fernandez-Viña R, Yalan AC, et al. Autologous bone marrow mononuclear cell (ABMMC) transplantation in type 1 and type 2 insulin-dependent diabetes mellitus patients. International Society of Cellular Therapy Meeting; 2007 June 24-27; Sydney.

Endereço para correspondência:

\section{Júlio César Voltarelli}

Hemocentro Regional de Ribeirão Preto,

Campus Universidade de São Paulo

14051-140 - Ribeirão Preto, SP

E-mail: jcvoltar@fmrp.usp.br 